\title{
PENGEMBANGAN MULTIMEDIA INTERAKTIF PADA MATERI LARUTAN PENYANGGA UNTUK SMA KELAS XI IPA
}

\author{
Anesia $^{1}$, Epinur $^{2}$, Yusnidar $^{3}$ \\ Prodi Pendidikan Kimia, Jurusan PMIPA, FKIP Universitas Jambi \\ 1email: anesiawahab@gmail.com \\ 2email: epinur63@unja.ac.id \\ 3email: yusnidar.fkip@unja.ac.id
}

\begin{abstract}
Abstrak
Ilmu kimia merupakan salah satu ilmu sains yang direpresentasikan ke dalam tiga level yaitu level makroskopik, level submikroskopik, dan level simbolik serta hubungan antara ketiga level ini harus secara eksplisit diajarkan. Untuk membantu siswa menghubungkan ketiga level representasi tersebut maka dibutuhkan suatu sumber belajar tambahan, misalnya multimedia interaktif.Penelitian ini bertujuan untuk mengetahui proses pengembangan multimedia interaktif pada materi larutan penyangga untuk siswa kelas XI IPA SMA Negeri 4 Kota Jambi, dan untuk mengetahui penilaian guru dan respon siswa terhadap multimedia yang dikembangkan.Penelitian ini merupakan penelitian pengembangan yang mengadaptasi kerangka pengembangan ADDIE (Analyze-Design-Develop-Implement-Evaluate).Instrumen penelitian yang digunakan adalah lembar wawancara dan angket. Data yang terkumpul diolah secara deskriptif menjadi data interval menggunakan skala Likert, dan dianalisis berdasarkan jumlah skor. Dari hasil penelitian menunjukkan bahwa multimedia interaktif pada materi larutan penyangga valid menurut ahli materi dengan skor 53 (sangat baik) dan ahli media dengan skor 52,3 (sangat baik). Selanjutnya dari hasil penilaian guru diperoleh skor 55 (sangat baik) dan respon siswa diperolehskor52,7 (sangat baik).Berdasarkan hasil penelitian secara keseluruhan dapat disimpulkan bahwa pengembangan multimedia interaktifpada tahap desainnya mengacu pada hasil analisis materi yang digambarkan dalam bentuk flowchart agar proses pengembangan media terarah, dan multimedia interaktif mendapat penilaian sangat baik dari guru dan siswa.
\end{abstract}

Kata kunci: Multimedia Interaktif, Larutan Penyangga

\begin{abstract}
Chemistry is a science that is represented into three levels that is macroscopic, submicroscopic, and symbolic. The relationship between these three levels must be taught explicitly. To help students to connect these three levels, we need an additional learning resource like interactive multimedia. This research aims to know the process of interactive multimedia development in the material buffer solution for eleventh grade students of Senior High School 4 Jambi and to know the teacher's assessment and student responses towardthis multimedia development. This research is a development research that adapting the development framework of ADDIE (Analyze-Design-Develop-Implement-Evaluate). The instrument of the researchis used interview and questionnaire. Thedata that have been collectedwas processed descriptively into interval data using Likert scaleand analyzed based on total score. The result of the research showed that interactive multimedia in material of buffer material is valid according to material expert with score 53 (very good) and media expert with score 52,3 (very good). Furthermore, from the results of teacher's assessment obtained score 55 (very good) and student responses obtained score52,7 (very good). Based on the results of the research as a whole we canconclude that the development of interactive multimedia in design phase refers to the results of material analysis that described in form of flowchart in order the development process of media is directed and interactivemultimedia get best assessment fromteacher and students.
\end{abstract}

Keywords: Interactive Multimedia, Buffer Solution 


\section{PENDAHULUAN}

Ilmu kimia merupakan ilmu yang diperoleh dan dikembangkan berdasarkan eksperimen yang mencari jawaban atas pertanyaan apa, mengapa, dan bagaimana gejala-gejala alam, khususnya yang berkaitan dengan komposisi, struktur, sifat, transformasi, dinamika dan energetika zat ${ }^{11}$. Salah satu karakter esensial dari ilmu kimia adalah pengetahuan kimia mencakup tiga level representasi, yaitu level makroskopik, level submikroskopik, dan level simbolik. Representasi level makroskopik adalah representasi kimia yang diperoleh melalui pengamatan nyata terhadap suatu fenomena yang dapat dilihat dan dipersepsi oleh pancaindra (misalnya perubahan suhu, pembentukan gas, dan endapan). Representasi level submikroskopik yaitu representasi kimia yang menjelaskan mengenai struktur dan proses pada level partikel (atom/molekul). Sedangkan representasi level simbolik adalah representasi kimia secara kualitatif dan kuantitatif, seperti rumus kimia, diagram, gambar, dan persamaan reaksi (Mashami, dkk, 2016).

Pada umumnya pembelajaran kimia saat ini hanya terbatas pada dua level representasi, yakni makroskopik dan simbolik, sedangkan level submikroskopik dipelajari terpisah dari level lainnya. Siswa diharapkan membangun sendiri pemahamannya pada level submikroskopik dengan cenderung hanya menghafalkan representasi submikroskopik yang bersifat abstrak akibatnya siswa tidak mampu untuk membayangkan bagaimana proses dan struktur dari suatu fenomena kimia. Untuk dapat mengintegrasikan pemahaman kimia pada ketiga level tersebut, ada banyak cara yang dapat ditempuh, salah satunya adalah dengan memanfaatkan alat-alat teknologi seperti komputer, karena dapat memvisualisasikan level submikroskopik dan menghubungkannya dengan level lainnya ${ }^{8)}$.

Berdasarkan infomasi yang didapat melalui wawancara bersama guru mata pelajaran kimia kelas XI SMA Negeri 4 Kota Jambi, diketahui bahwa terdapat beberapa permasalahan yang terjadi selama proses pembelajaran pada materi larutan penyangga. Guru masih menggunakan metode ceramah yang meskipun dapat menyatukan pemahaman siswa namun cenderung membosankan. Selain itu, juga pernah digunakan metode eksperimen namun metode ini sangat tergantung terhadap ketersediaan waktu dan bahan di laboratorium.Setelah dilakukan penelusuran lebih mendalam melalui penyebaran angket kepada beberapa siswa di kelas XI SMA Negeri 4 Kota Jambi, ternyata $53,33 \%$ siswa mengaku mengalami kesulitan dalam mempelajari 
materi larutan penyangga. $60 \%$ siswa berpendapat bahwa penjelasan guru saja tidak cukup bagi mereka untuk memahami materi larutan penyangga.Hasil lain yang diperoleh dari penyebaran angket yaitu $100 \%$ sampel siswa kelas XI IPA merasa membutuhkan penggunaan media pembelajaran untuk materi larutan penyangga. Hal ini cukup memungkinkan untuk dilaksanakan karena sarana dan prasarana ICT seperti laboratorium komputer, infocus, LCD proyektor, dan jaringan internet telah memadai di SMA Negeri 4 Kota Jambi. Dengan demikian, solusi yang paling memungkinkan untuk mengatasi kesulitan belajar siswa pada materi larutan penyangga adalah penggunaan media pembelajaran.

Salah satu media pembelajaran baru yang akhir-akhir ini semakin membantu tugas guru adalah teknologi multimedia interaktif yang tersedia melalui perangkat komputer. Dengan teknologi ini, kita bisa belajar apa saja, kapan saja dan di mana saja $^{4)}$. Multimedia interaktif merupakan solusi yang tepat dalam meningkatkan kualitas pembelajaran kimia, peserta didik akan sangat tertolong dalam menghubungkan ketiga representasi kimia, karena multimedia interaktif mampu membuat materi pelajaran terasa nyata karena tersaji dengan kasat mata, dapat merangsang berbagai indera untuk berinteraksi, visualisasi dengan bentuk teks, gambar, audio, video dan animasi akan lebih diingat dan ditangkap oleh siswa ${ }^{6}$.

Multimedia interaktif dipilih karena jenis media ini memiliki berbagai keunggulan yang bersesuaian dengan karakteristik materi larutan penyangga, di antaranya dapat memperbesar benda yang sangat kecil dan tidak tampak mata, dan dapat menyajikan peristiwa yang kompleks, rumit, dan berlangsung cepat atau lambat ${ }^{4}$. Dengan demikian, penggunaan multimedia interaktif diharapkan dapat membantu kesulitan belajar pada materi larutan penyangga.

\section{METODE PENELITIAN}

Jenis penelitian ini adalah penelitian pengembangan (Research and Development), seperti yang dapat dilihat pada rumusan masalah yang diungkap sebelumnya. Dalam penelitian pengembangan ini dihasilkan produk baru berupa multimedia interaktif. Penulis memilih kerangka pengembangan ADDIE (Analyze-Design-Develop-ImplementEvaluate).

Subjek penelitian penelitian dalam uji coba ini hanya sebatas uji coba kelompok kecil yaitu 15 orang siswa kelas XI IPASMA Negeri 4 Kota Jambi.

Instrumen penelitian yang digunakan adalah lembar wawancara dan angket. 
Penentuan klasifikasi validasi oleh ahli media, ahli materi, dan penilaian oleh guru diolah secara deskriptif menjadi data interval menggunakan skala Likert, dan dianalisis berdasarkan jumlah skor.

Deskriptor dalam angket yang diberikan pada validasi ahli materi, ahli materi, dan penilaian oleh guru sebanyak 15 pertanyaan, sehingga secara teoritik akan memperoleh skor minimal 15 dan maksimal 60 dimana interprestasi skor tersebut adalah sebagai berikut:

- Skor minimum: $1 \times 15$ (deskriptor yang dinilai) $=15$

- Skor maksimal: $4 \times 15$ (deskriptor yang dinilai) $=60$

- Kategori kriteria: 4

- Jarak interval (i) : skor tertinggi - skor terendah Jumlah kelas interval $=\frac{60-15}{4}=11,25$

Tabel 1 Kategori Tingkat ValidasiBerdasarkan

\begin{tabular}{|c|c|c|c|}
\hline Nomlah Skor \\
\hline 1 & $\begin{array}{c}\text { Skala } \\
\text { Nilai }\end{array}$ & Skor & $\begin{array}{c}\text { Tingkat } \\
\text { Validasi }\end{array}$ \\
\hline 2 & 3 & $\begin{array}{c}>37,50 \mathrm{~s} / \mathrm{d} \\
48,75\end{array}$ & $\begin{array}{c}\text { Sangat } \\
\text { baik }\end{array}$ \\
\hline 3 & 2 & $\begin{array}{c}>26,25 \mathrm{~s} / \mathrm{d} \\
37,50\end{array}$ & Tidak baik \\
\hline 4 & 1 & $15 \mathrm{~s} / \mathrm{d} 26,25$ & $\begin{array}{c}\text { Sangat } \\
\text { tidak baik }\end{array}$ \\
\hline
\end{tabular}

\section{HASIL PENGEMBANGAN DAN PEMBAHASAN}

Hasil dari penelitian pengembangan ini adalah berupa multimedia interaktif pada materi larutan penyangga. Pengembangan multimedia interaktif ini dilakukan menggunakan kerangka pengembangan ADDIE yang terdiri dari 5 tahap, yaitu: Analisis (Analyze), Desain (Design), Pengembangan (Develop), Implementasi (Implement), dan Evaluasi (Evaluate). Hasil dari tiap tahapan tersebut dijabarkan sebagai berikut:

\section{Analisis (Analyze)}

Tahap analisis dilakukan untuk menetapkan acuan dasar pengembangan multimedia. Analisis dilaksanakan melalui wawancara dengan guru kimia dan penyebaran angket kepada siswa, yang berguna untuk mengumpulkan data terkait permasalahan yang dihadapi guru dan siswa kelas XI SMA Negeri 4 Kota Jambi. Data yang diperoleh ditinjau dari aspek kebutuhan, materi, karakteristik siswa, dan sumber daya.

\section{Desain (Design)}

Pada tahap ini dilakukan perancangan multimedia interaktif yang telah disesuaikan dengan informasi yang telah diperoleh pada tahap analisis. Langkah yang dilakukan pertama kali adalah membuat flowchart atau diagram alur dari 
multimedia interaktif patokan pengembangan multimedia. Pembuatan flowchart ini mengacu kepada indikator dari materi pokok larutan penyangga. Selain itudilakukan pula pembuatan storyboardyangmerupakan proses lanjutan dari pembuatan flowchart. Pada storyboard akan terlihat rancangan tampilan multimedia interaktif yang dilengkapi keterangan mengenai halaman multimedia tersebut.

\section{Pengembangan (Develop)}

Tahap pengembangan merupakan proses mewujudkan storyboard yang telah dibuat sebelumnya agar menjadi produk yang ingin dihasilkan, yaitu multimedia interaktif untuk materi larutan penyanggayang kemudian divalidasi oleh ahli media dan ahli materi.

\section{Validasi materi pada multimedia interaktif dilaksanakan dengan} memperhatikan tiga aspek sebagaimana yang dikemukakan oleh ${ }^{10)}$. yakni aspek format, isi, dan bahasa. Dalam proses validasi materi, ahli materi menyarankan untuk memperbaiki aspek isi yakni kejelasan kompetensi inti, kompetensi dasar dan indikator pembelajaran, kelengkapan materi berdasarkan indikator pembelajaran, kesesuaian gambar dalam mendukung penjelasan materi larutan penyangga,dan kejelasan contoh soal.
Adapun salah satu contoh perbaikan yang dilakukan sesuai saran ahli materi yaitu:

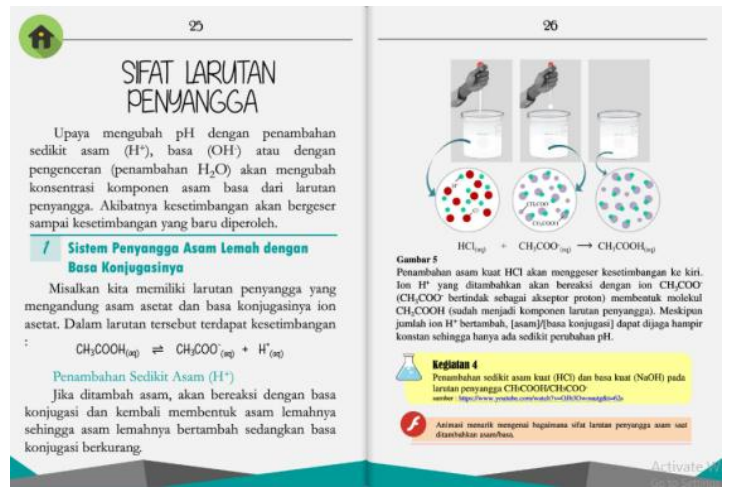

(a)

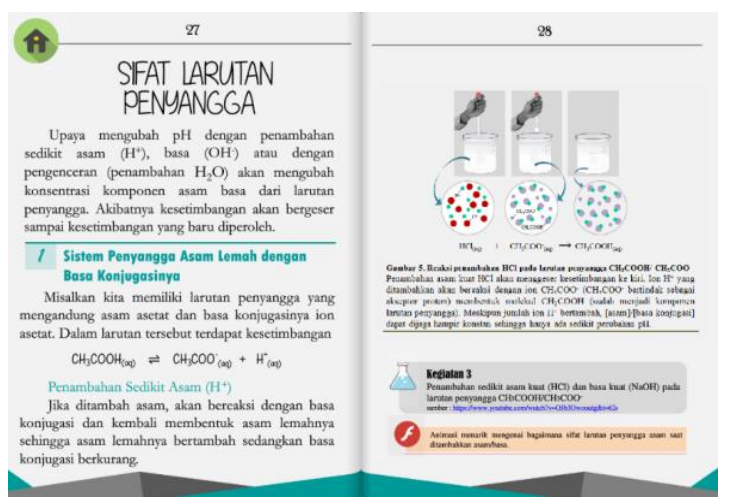

(b)

Gambar 1 Kesesuaian Gambar dalam Mendukung Penjelasan Materi Larutan Penyangga (a) Sebelum di Revisi (b) Sesudah di Revisi

Setelah melalui dua kali tahap validasi, multimedia yang peneliti kembangkan mendapat hasil penilaian yang baik dan dinyatakan layak uji coba oleh ahli materi dan memperoleh jumlah skor sebesar53 sehingga multimedia interaktif dikategorikan "sangat baik".

Selanjtnya validasi oleh ahli media. Validasi media memperhatikan enam aspek, antara lain meliputi aspek 1) Kesederhanaan; 2) Keterpaduan; 3) Penekanan; 4) Keseimbangan; 5) Bentuk; dan (6) Warna ${ }^{3)}$. Dalam proses validasi 
media, keenam aspek ini mendapat komentar dan saran perbaikan tanpa terkecuali. Adapun salah satu contoh perbaikan yang dilakukan sesuai saran ahli media yaitu:

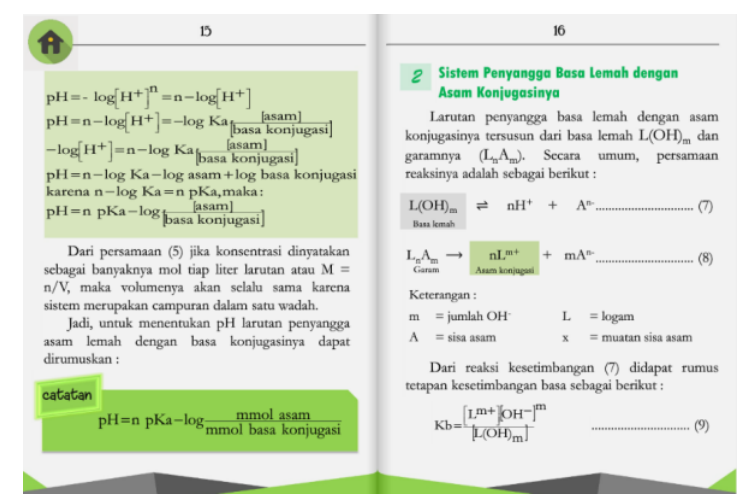

(a)

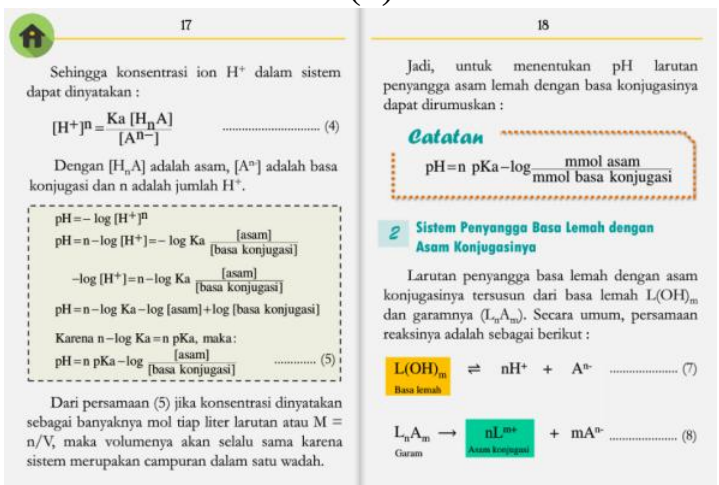

(b)

Gambar 2 Kualitas Penekanan oleh Setiap Komponen dalam Multimedia (a) Sebelum di Revisi (b) Sesudah di Revisi

Setelah melalui tiga kali tahap validasi, multimedia yang penulis kembangkan mendapat hasil penilaian yang baik dan dinyatakan layak uji coba oleh ahli media dan memperoleh jumlah skor sebesar52,3 sehingga multimedia interaktif dikategorikan "sangat baik".

\section{Implementasi (Implement)}

Sebelum dilakukan uji coba dikelas,produk multimedia yang telah divalidasi dinilai kelayakannya oleh seorang guru kimia di SMA Negeri 4 Kota Jambi.Dari penilaian guru tersebut diperoleh saran perbaikan berupa penggantian kata-kata yang digunakan, penggantian warna background dan penambahan pembahasan pada soal evaluasi.Di luar saran tersebut, guru tetap memberikan penilaian yang baik dan menyatakan multimedia interaktif layak untuk diuji cobakan.

Ujicoba yang dilakukan yaitu ujicoba kelompok kecil dengan jumlah 15 siswa kelas XI IPA di SMAN 4 Kota Jambi. Dari hasil angket respon siswa terhadap multimedia interaktif pada materi larutan penyangga yang telah dikembangkan memperoleh skor 52,7yang bila di konversikan kedalam kategori tingkat validasi, maka termasuk dalam katergori "sangat baik" yang dapat dilihat pada pada Tabel 1.

Adapun komentar siswa secara umum terhadap multimedia interaktif yang diujicobakan antara lain:

1. Tampilan multimedia sangat menarik sehingga membuat saya tertarik untuk belajar menggunakan multimedia interaktif.

2. Secara keseluruhan tampilan media sudah sangat menarik dengan pilihan menu yang dapat langsung diklik dan dapat mempermudah siswa dalam belajar, namun menurut saya lebih baik 
jika tulisannya diperbesar.

3. Warna sangat menarik, sehingga tidak membosankan dan membantu dalam memahami konsep larutan penyangga.

Berdasarkan komentar tersebut, penulis menyimpulkan bahwa multi-media interaktif pada materi larutan penyangga yang dikembangkan terbukti dapat memudahkan siswa untuk lebih memahami materi larutan penyangga.

\section{Evaluasi (Evaluation)}

Evaluasi adalah proses untuk melihat apakah media pembelajaran yang sedang dibuat berhasil sesuai dengan harapan awal atau tidak. Evaluasi dapat dilakukan di setiap tahap pengembangan. Sedangkan evaluasi terakhir dilakukan untuk mengetahui respon siswa terhadap penggunaan media pembelajaran yang telah dinyatakan layak oleh tim ahli. Pada akhir tahap implementasi (uji coba produk), diperolehlah data berupa angket yang merupakan bahan yang dievaluasi pada akhir kerangka ADDIE.

Dari data angket respon siswa kelas XISMANegeri 4 Kota Jambi, diperoleh respon yang sangat baik dimana sebagian besar siswa memberikan komentar bahwa multi-media interaktifmudahdioperasikan serta kemenarikan penyajian materi yang disajikan mampu membuat siswa tertarik dalam mempelajari materi larutan penyangga dan dapat membantu mereka untuk lebih mudah dalam memahami materi larutan penyangga.

\section{KESIMPULAN}

Berdasarkan hasil penelitian dan pembahasan tentang pengembangan multimedia interaktif pada materi larutan penyangga untuk siswa kelas XI SMANegeri 4 Kota Jambi, maka dapat ditarik kesimpulan sebagai berikut:

1. Produk multimedia interaktif yang dihasilkan pada penelitian ini menggunakan software 3D Pageflip Professional yang dikembangkan melalui kerangka pengembangan ADDIE (Analyze-Design-DevelopImplement-Evaluate). Pada tahap desain harus memperhatikan hasil analisis materi pada tahap sebelumnya, dimana untuk materi larutan penyangga membutuhkan simulasi dan video. Kemudian, sebelum dilanjutkan ke tahap pengembangan, harus dibuat flowchart terlebih dahulu agar proses pengembangan berjalan dengan tahapan dan langkah-langkah yang jelas dan terstruktur.

2. Multimedia interaktif yang telah dikembangkanmendapat respon sangat baik dari guru dan siswa. 


\section{DAFTAR RUJUKAN}

1 . 2006, Standar Isi untuk Satuan Pendidikan Dasar dan Menengah. Jakarta: Depdiknas.

2. Arsyad, A., 2015, Media Pembelajaran. Jakarta: Rajawali Press.

3. Daryanto., 2016, Media Pembelajaran. Yogyakarta: Gava Media.

4. Johari, J.M.C and Rachmawati, M., 2010, Chemistry 2B for Senior High School Grade XI Semester 2. Jakarta : Esis.Mashami, R. A., Andayani, Y., dan Gunawan, 2016, Pengaruh Media Animasi Submikroskopik terhadap Peningkatan Kemampuan Representasi Siswa, JurnalIlmiah Pendidikan Kimia "Hydrogen", 2(1): 149-152.

5. Munir., 2015, Multimedia Konsep \& Aplikasi dalam Pendidikan. Bandung: Alfabeta.
6. Sudarmo, U., 2014, Kimia untuk SMA/MA Kelas XI. Surakarta: Erlangga.

7. Sulistyowati, T., dan Poedjiastoeti, S., 2013, Kelayakan Multimedia Interaktif Berbasis Intertekstual Pada Materi Reaksi Kimia untuk Kelas X SMA, Unesa Journal of Chemical Education, 2(3): 57-63.

8. Widoyoko, E., 2016, Teknik Penyusunan Instrumen Penelitian. Yogyakarta: Pustaka Pelajar.

9. Yamasari, Y., 2010, Pengembangan Media Pembelajaran Matematika Berbasis ICT yang Berkualitas, Makalah dipresentasikan pada Seminar Nasional Pascasarjana X - ITS, 4 Agustus, Surabaya. 